\title{
DA TRADUÇÃO COMO ATO CRIADOR: RAZÕES E DESRAZÕES DE UMA NEGAÇÃO ${ }^{1}$
}

\author{
Jean-Yves Masson \\ Université Paris-Sorbonne, Paris, ̂̂le-de-France, França \\ Tradução de Jaqueline Sinderski Bigaton ${ }^{1}$ \\ Francisca Y. M. Reyes Silveira 1 \\ ${ }^{1}$ Universidade Federal de Santa Catarina, Florianópolis, Santa Catarina, Brasil
}

\begin{abstract}
Resumo: O texto intitulado " $\mathrm{Da}$ tradução como ato criador: razões e desrazões de uma negação", escrito por Jean-Yves Masson, foi originalmente publicado na Revista Meta no ano de 2017 e trata sobre a tradução como um ato de criação, sobre o papel do tradutor como criador e sobre o fato de que a tradução ainda é vista como uma atividade secundária e meramente mecânica.
\end{abstract}

Palavras-chave: Tradução; Criação; Estudos da Tradução

\section{TRANSLATION AS A CREATIVE ACT: REASONS AND NO REASONS FOR A NEGATION}

\begin{abstract}
The text entitled "Translation as a creative act: reasons and reasons for a denial", written by Jean-Yves Masson, was published in Meta Magazine in 2017 and deals with translation as an act of creation, about the role of the translator as the fact that translation is still seen as a secondary and merely mechanical activity.
\end{abstract}

Keywords Translation: Creation; Translation Studies \footnotetext{
Revista Meta no ano de 2017.

${ }^{1}$ Tradução do texto intitulado "Da tradução como ato criador: razões e desrazões de uma negação", escrito por Jean-Yves Masson, originalmente publicado na 


\section{Introdução}

Que a tradução não seja "criadora" é o lugar comum mais difundido sobre esse tema, justificando o desdém milenar ao qual foi relegada no Ocidente. Lembramo-nos do diálogo entre um geômetra e um tradutor nas Cartas persas de Montesquieu:

- [...] faz vinte anos que me ocupo de fazer traduções.

- Quê? Meu senhor, faz vinte anos que não pensais? Falais pelos outros e eles pensam por vós? - exclamou o geômetra. (Montesquieu 205)

Estaríamos enganados ao acreditar que essa troca, que leva aparentemente a uma condenação da tradução, reflete em primeiro grau o pensamento do próprio Montesquieu: trata-se de uma espécie de mise en abîme discreta e irônica da natureza própria das Cartas persas, nas quais o autor (sempre mantendo o anonimato) apresenta-se em sua introdução, não esqueçamos, como o simples tradutor. O original das Cartas está, claro, supostamente em persa, e ele mesmo, para as traduzir, alega tê-las tirado da atenção de seus verdadeiros autores. Como se se tratasse de uma ficção que Montesquieu nem ao menos procurou tornar crível, nenhum leitor pode se confundir sobre o fato de que as Cartas persas são uma pseudo-tradução que mascara, na verdade, um original.

$\mathrm{O}$ que quis o autor das Cartas persas com esse preâmbulo, certamente, foi enfatizar o artifício que é o caráter de seu livro: dar a ver seu próprio país pelos olhos de estrangeiros que se espantam com aquilo que parece natural aos autóctones. Mas, então, trata-se também, para ele, de utilizar o francês ao mesmo tempo que faz ressoar um pensamento vindo de fora, obedecendo a modos de pensar que não são franceses. Trata-se de introduzir algo estrangeiro na língua, de escrever como se ele traduzisse uma língua estrangeira. Com certeza, o falso tradutor não esquece, para assegurar seu leitor, de dizer que cortou certas características demasia- 
do orientais. As Cartas poderão, então, ser lidas "como um livro francês"... Montesquieu, sob sua máscara, finge assim preencher o "pacto de leitura" que todo[a] tradutor[a], à época clássica, deve assinar com seu público: espera-se dele que adapte (mesmo que a palavra não existisse ainda nesse sentido!), removendo tudo o que possa chocar ou incomodar o bom gosto francês. Assim se explica o fato de que Uzbek e seus compatriotas, mesmo sendo persas, se exprimem como perfeitos cavalheiros parisienses.

Mas não é óbvio que Montesquieu pretende, assim, enfatizar que, se ele fosse realmente um tradutor, precisamente, ele não permaneceria passivo frente ao texto a ser traduzido? Longe de se abster de pensar, como crê o geômetra da carta 128 , ele interviria mesmo maciçamente, como era tão frequente o costume de sua época, não hesitando em cortar seções inteiras do texto. Cervantes, em Dom Quixote, outra tradução fictícia (o original do livro, lembremos, deveria ser um manuscrito redigido em árabe), empregou o mesmo tipo de lembretes periódicos, indicando em alguns capítulos que diminuíra os comprimentos da narrativa inicial.

No entanto, o mais importante não está lá: a ficção que emprega Montesquieu serve para introduzir no espírito do leitor uma distância relativa ao texto, que permitirá desculpar as maneiras de pensar "bárbaras" de um estrangeiro levado a emitir, sobre a França, afirmações que talvez não seriam toleradas se fossem da parte de um francês. A obra estrangeira é, portanto, mais "naturalmente" escandalosa para o leitor, que não poderia se ofender completamente com os persas por não terem os mesmos modos de pensar de seu próprio país. Montesquieu, certamente, nada tem a ver com isso: ele é, como o diz em sua tentativa particular de captatio benevolentice, "somente" o tradutor.

É muito alentador, mas com toda evidência falso, separar tradução e criação como duas esferas que não se comunicam. Um livro, afirma a doxa, é escrito por seu autor, depois traduzido por tradutores[as], que então não saberiam fazer uma obra "original", pois eles não têm o direito. A primeira evidência de que existe um texto primeiro e um texto segundo - ou seja, como diria Monsieur 
de La Palisse, é preciso, para traduzir um livro, que esse tenha sido, primeiramente, escrito - é, assim, subrepticiamente transposto, transcrito em uma distinção entre "original" e "cópia"; o[a] tradutor[a] devendo se abster, alega-se, de toda forma de "criação", se ele[a] quiser fazer justiça à obra que traduz. $\mathrm{O}$ [a] tradutor[a] deve "apagar-se" até tornar-se invisível: esse imperativo junta-se ao ideal bem conhecido da tradução "transparente", que se faz esquecer como tal. Ora, nós bem o sabemos, esse apagamento nunca é absoluto. Nunca é completamente possível, e impossibilitado[a] de poder se apagar (pois as palavras que ele[a] escolhe para traduzir são as suas e não aquelas de outro[a] tradutor[a], que entregará um resultado diferente), o[a] tradutor[a] busca se fazer esquecer, o que está longe de ser a mesma coisa. E o que, talvez, nunca possa ser inteiramente possível: esse é o objeto da presente reflexão.

\section{O regime fiduciário da tradução}

Não podemos esquecer que o nascimento de um verdadeiro pensamento da tradução, cujas premissas estão no romantismo alemão, e que se tornaria a "tradutologia" no século XX, coincidiu com a consciência da insuficiência dos estereótipos tradicionais que acabamos de lembrar e com o desejo de reabilitar o[a] tradutor[a], mostrando que seu papel em relação a um texto não pode ser passivo. Mas até onde vão os direitos do[a] tradutor[a]? É ele[a] um[a] escravo[a] a serviço da obra que traduz? As mesmas pessoas que lhe negam o direito de se reivindicar criador[a] serão as primeiras a criticar uma tradução "servil", ou seja, "palavra por palavra", que a tradição ocidental recusa quase unanimemente desde Cícero. É para evitar as aporias, à quais é conduzido rapidamente um pensamento desse tipo, que termos como "fonte" e "alvo" foram escolhidos, evitando o registro impreciso e suspeito de "originalidade". A questão da criação na tradução aparece, então, sob um novo ângulo e pode ser desenvolvida da seguinte forma: quanto de autoria o[a] tradutor[a] possui no objeto "tradução"? 
Essa questão não é fácil de resolver e até mesmo aborda aquilo que incomoda os historiadores de literatura e os críticos em uma tradução. Monsieur de La Palisse, aqui também, tem o que dizer e sua fala está longe de ser irrelevante: se lhe perguntarmos do que o tradutor é autor, responderá que é o autor... da sua tradução. Como objeto literário, um livro traduzido possui, na realidade, dois[duas] autores[as]: o[a] autor[a] do texto fonte e o[a] tradutor[a] como sendo "autor" do texto alvo. Do qual nem uma palavra, sem dúvida, poderia ter sido escrita sem o texto primeiro, do qual nenhuma frase existe por si só, mas é apenas referência a uma ou mais... frases do texto fonte, mas sem que eu possa ser capaz de identificar com certeza a parte subjetiva, que pertence ao[à] tradutor[a]. Para começar a apreciar essa parte, é necessário comparar (ao menos) duas traduções do mesmo texto, realizadas por dois[duas] tradutores[as] diferentes: as diferenças que aparecem, e que não podem deixar de aparecer, manifestam essa parte da subjetividade do[a] tradutor[a] que entra na composição do texto que lemos, sem que se trate necessariamente de erros cometidos por um[a] deles[as]. Subjetividade não quer dizer arbitrariedade: se cada tradutor[a] tem seu próprio modo de compreender o texto, é porque ele[a] é, primeiro, um[a] leitor[a]. E sabemos, desde Proust, que um livro contém tantos livros diferentes quanto terá leitores: ninguém vê de fato a mesma coisa, mesmo que todos leiam o mesmo livro.

Entretanto, o estatuto normal, o regime ordinário da tradução não é de se oferecer a tal leitura comparada. Quando eu leio uma obra traduzida, a totalidade de palavras que leio foram escritas pelo[a] tradutor[a]; nenhuma palavra mais é, por definição, "do"[a] autor[a]. Não paramos de nos inclinar para o abismo que essa constatação muito simples abre, tão simples e tão vertiginosa que, na maior parte do tempo, é objeto de uma completa negação (e eu emprego esse termo no sentido que lhe dá a psicanálise, remetendo à necessidade de aprofundar essa questão mais tarde). Pois, a despeito dos ensinamentos que se pode tirar da comparação entre inúmeras traduções de um mesmo texto, não existe eletrólise que 
permita separar o oxigênio trazido pelo[a] autor[a] do hidrogênio que o[a] tradutor[a] enxertou nele. O texto traduzido é uma água que eu bebo sem poder dizer de quem vem.

Obviamente, essa não é uma coisa agradável de se pensar, pois todo mundo deseja extrair diretamente da fonte. Tenho interesse, então, já que não posso fazer diferentemente (pois a primeira função da tradução é dirigir-se aos leitores que não tem domínio da língua de origem e devem, assim, passar por uma tradução para poder ter acesso à obra), para minha paz de espírito, em esquecer o máximo possível de que, o que li, não é a obra original. O que desejo é ser capaz de pensar (e de dizer) que li Les Frères Karamazov [Os irmãos Karamazov]. Apenas um exame minucioso revelará o abismo que separa, para citar apenas três, a primeira tradução de Halperin-Kaminski e Charles Morice (1888), também qualificada como adaptação pelos próprios tradutores, da tradução de Boris de Schloezer (1929) e, por sua vez, da tradução de André Markowicz (2002). Segundo a tradução que eu escolhi, simplesmente não li a mesma obra: claro, a história e as personagens são as mesmas, mas elas não falam, de forma alguma, a mesma língua e não são... as mesmas. Escolhi aqui um caso no qual o último tradutor, Markowicz, expôs seus princípios de tradução e denunciou a linguagem acadêmica, com a qual Dostoiévski foi traduzido antes dele, como não correspondendo ao que Dostoiévski era em russo. O leitor que ouve e não pode verificar por si mesmo esses argumentos, é capaz de se informar sobre esse debate, mas não pode dar razão a Markowicz nem reabilitar Boris de Schloezer com conhecimento de causa. Ele, portanto, pega o que lhe é dado e deve aceitar se deixar guiar pelo tradutor: deve confiar nele. O regime da tradução é um regime fiduciário. Não posso fazer diferente, além de tomar as palavras do[a] tradutor[a] como favas contadas. Desconfiar disso não me trará nada, já que não posso fazê-lo com conhecimento de causa - a menos que possa controlar eu mesmo a tradução e, ainda assim, não sou o leitor "normal" da tradução, sou um pedagogo que procura verificar se pode recomendar essa tradução 
aos seus alunos, ou um colega de tradução que procura avaliar o seu trabalho, ou um curioso perverso que lê uma tradução ao invés de ler um trabalho original (essa perversão, certamente, é legítima). E é por isso que todos os prefácios de tradutores[as], desde que existem (o primeiro a ser conservado foi o De optimo genere oratorum [O melhor gênero de oradores], de Cícero), são também esforços para conciliar a benevolência do[a] leitor[a]: é necessário que ele[a] adira ao texto que é lhe submetido e ceda ao[à] tradutor[a] sua confiança.

Mas essa confiança, sem dúvidas, nunca será plena e completa e é, sem dúvidas, menor, já que a consciência literária do[a] leitor[a] é mais desenvolvida. Que o[a] tradutor[a] reivindique seu lado criativo (intervindo no texto para facilitar a leitura) ou o negue (sendo rigorosamente fiel ao original), não pode afastar completamente a suspeita que paira sobre ele[a]. O[a] leitor[a] que tropeça em uma aspereza, primeiro acusará o[a] tradutor[a] de inaptidão, enquanto talvez não seja nada e que o texto fonte apresente uma aspereza similar, na qual o tradutor se reteve até encontrar um equivalente.

$\mathrm{O}$ [a] tradutor[a] sabe que será o[a] primeiro[a] acusado[a], se o[a] leitor[a] tiver o sentimento de que "algo não flui" na língua alvo, e é por isso que a tentação de apagar essas asperezas é grande, de "suavizar" o texto para não inquietar o[a] leitor[a]. O que Antoine Berman $(1985$; 1991) interpretou exclusivamente, erroneamente a meu ver, em termos de etnocentrismo ${ }^{2}$, compreendo, a princípio, como essa preocupação de se proteger da suspeita, que sempre renasce, do[a] leitor[a] em relação ao[à] tradutor[a]. Os reflexos etnocêntricos vêm apenas em segundo lugar e são apenas uma consequência da submissão do[a] tradutor[a] aos critérios que lhe asseguram, ele[a] acredita, uma comunicação mais fluida com o[a] leitor[a]. A suspeita pode ser afastada somente quando o[a] tradutor[a] é, excepcionalmente, reconhecido[a] pela sua qualidade literária: Amyot e Baudelaire são, em francês, arquétipos desse tipo

${ }^{2}$ Berman, sabe-se, opõe a tradução "etnocêntrica" ocidental à tradução "ética", que ele defende, na qual a alteridade do estrangeiro é reconhecida como tal, e não é apagada.

Cad. Trad., Florianópolis, v. 39, no 3, p. 486-506, set-dez, 2019. 
de consagração. Li as Vies [Vidas] de Plutarco traduzidas por Amyot como uma obra francesa, pois é admitido que faz parte da nossa literatura. Da mesma forma, o Homero de Pope pertence completamente à literatura inglesa, ao ponto que sua leitura seja uma obrigação para todo[a] leitor[a] inglês[a] culto[a], sem que ele[a] tenha que se perguntar até que ponto Homero se beneficia com isso. Essas traduções consagradas estão livres de toda suspeita, pois as mesmas quase perderam o estatuto de traduções para conquistar o de obras completas e totalmente reconhecidas como tal.

\section{A criatividade do[a] tradutor[a]: uma realidade reprimida pela história literária e pela lexicografia}

Mas essas são exceções. Modulemos novamente nosso ponto. De fato, quanto mais literária é a obra a ser traduzida, mais culto é o público para a qual é destinada, e é ainda mais possível para o[a] tradutor[a] pedir paciência ao[à] seu[sua] leitor[a] - muitas "notas do[a] tradutor[a]" têm a função de convidar o[a] leitor[a] para "o ateliê" do[a] tradutor[a], o[a] qual elucida as dificuldades para o[a] primeiro[a]. O ponto extremo dessa prática é alcançado nas fascinantes traduções da Bíblia por Henri Meschonnic (2002): cada volume é acompanhado por uma grande quantidade de notas nas quais o tradutor compartilha com o[a] leitor[a] a reflexão que o levou a adotar a tradução proposta. Entramos no laboratório do poeta-tradutor, consultando os dicionários, refletindo sobre as raízes semânticas, tateando até encontrar sua solução. O texto é impresso sem notas, porque, do contrário, estariam por toda parte; cabe ao[à] leitor[a] deslocar-se, indo e voltando entre o texto e as notas, se ele[a] desejar, após ter lido o texto uma primeira vez por si próprio[a]. É esse dispositivo singular que permite ao tradutor liberar sua criatividade poética: na tradução da passagem de Genèse, 11 [Gênesis 11], sobre a torre de Babel, quando Meschonnic substitui "confondons leurs langues" ["confundamos

Cad. Trad., Florianópolis, v. 39, no 3, p. 486-506, set-dez, 2019. 
suas línguas"] por sua própria solução, “embabelons leurs langues" ["embabelemos suas línguas"] (63), ele inventa uma palavra e brinca, como poeta que é, com todas as possibilidades da língua francesa. Processo crítico exposto em nota e processo criativo em ação no conjunto de decisões inovadoras que, assim, conduzem a uma completa recomposição do texto.

Para textos de valor literário mais fraco, incluindo os textos de consumo muito grande, ao contrário, a demanda do público é prioridade: o[a] "cliente"-leitor[a] é rei[rainha] e o imperativo imposto pelo[a] editor[a] ao[à] tradutor[a] é fornecer o texto o mais límpido, o mais “consumível” possível. É, portanto, muito frequente em textos pertencentes à paraliteratura que a criatividade do[a] tradutor[a] seja solicitada da maneira mais óbvia! Basta olhar, por exemplo, para a inventividade demonstrada pelos tradutores de Harry Potter em todas as línguas para compreendê-lo e, particularmente, em francês, notadamente na recriação de nomes próprios. Notas de rodapé são proibidas (porque o público jovem não admitiria), pois tudo deve ser compreendido imediatamente.

Alguns[as] tradutores[as] acham que essa também é a regra para a tradução literária "de grande envergadura" e que sempre deve-se proibir as notas de rodapé: eu não concordo, pois me parece ser essencial adaptar-se à natureza das obras, ao seu grau de afastamento cultural em relação ao leitor da língua alvo, etc. Porém, acabamos de ver, pelo exemplo de Meschonnic, que não devemos pensar que a criatividade do[a] tradutor[a] diminui na medida em que a qualidade literária do texto aumenta! A realidade é muito mais complexa: a criatividade do[a] tradutor[a] é, sem dúvidas, menos aceita como tal quando a obra a ser traduzida é beneficiada com o estatuto de obra-prima, já que o[a] leitor[a] não gosta da ideia de que alguém se interponha entre ele[a] e o[a] autor[a] que deseja compreender por si mesmo[a]. A parte criativa do[a] tradutor[a] será, então, frequentemente minimizada voluntariamente, até mesmo ocultada por essa última. Mas há mil exceções para essa afirmação: esperamos de um[a] tradutor[a], que traz uma nova versão de Alice au pays des merveilles [Alice 
no país das maravilhas], que proponha novas soluções - a tradução de tal livro (e de todos os livros e poemas de Lewis Carroll em geral) obriga o[a] tradutor[a] a assumir riscos se quiser que seu trabalho seja de interesse.

Devemos, portanto, admitir a inquietação fundamental que rodeia a tradução e nos acostumar com seu estatuto de objeto literário incerto, mas essencial. Isso levará ao fim da repressão da qual é objeto na história literária, principalmente na França, em que nenhuma história da literatura francesa, até agora, considerou que os[as] tradutores[as] também poderiam ter o estatuto de autores[as]. Sempre escrevemos apenas a história de obras "originais”. Podemos, às vezes, mencionar as imitações como tal, mas quase nunca as traduções: tudo acontece como se nunca tivessem desempenhado o menor papel na vida literária dos séculos passados. Quando mencionamos que tal autor[a] francês foi "influenciado[a]" (essa palavra mágica, infelizmente, ainda não desapareceu) por obras estrangeiras, jamais nos perguntamos quais traduções ele[a] utilizou como recurso e agimos como se ele[a] tivesse lido todas na língua original - o que às vezes é verdade, com certeza, mas não muito comum.

Esse "esquecimento" da tradução resulta diretamente da negação da criatividade que se opõe a ela: o[a] tradutor[a] deve permanecer na sombra, somente os[as] autores[as] têm o direito de aparecer em cena. Esse preconceito, que ainda não foi contestado, na França, pelos[as] historiadores[as] da literatura (mas que já é bem diferente em muitos países francófonos), não reina no mesmo grau que em outras áreas linguísticas e culturais: os[as] alemães[ãs], por exemplo, sabem há muito tempo que lhes é impossível escrever a história da sua literatura sem levar em conta as traduções. Mas é porque, na verdade, a língua alemã moderna foi forjada por uma tradução, a tradução da Bíblia por Lutero, e que essa inscrição da tradução no próprio nascimento da língua impede toda repressão, todo esquecimento. Não obstante, as outras literaturas não deveriam poder negar o papel que as traduções desempenham na maturação e evolução de qualquer língua. 
É possível constatar esse papel de maneira mais espetacular no alemão; e é muito possível que varie conforme as línguas (uma vasta investigação deve ser conduzida). Mas somente uma história geral das traduções permitirá verificar esse fato. Digamos, então, por enquanto, as coisas em dupla negação: provavelmente não existe nenhuma língua de cultura em maturação na qual as traduções não tenham exercido nenhum papel.

A questão da língua é de fato essencial quando refletimos sobre o papel criador desempenhado pelos[as] tradutores[as]. Pois a visão errônea da história literária que evoquei encontra sua extensão direta nos dicionários: e aqui, novamente, a situação difere de acordo com o país. Os dicionários de língua francesa que recorrem a citações de grandes autores[as] para ilustrar os usos de uma palavra, desde Littré, emprestam somente do corpus de nossos[as] grandes autores[as]. Quase nunca citamos os usos que podem ter sido feitos por tradutores[as]. Se eu olhar para a "Liste des auteurs et des ouvrages cités" ["Lista de autores e de obras citadas"], no início do Grand Robert [dicionário Grand Robert] (possuo a edição de 1980), encontrarei somente uma tradução: como deve-se mencionar a Bíblia, indicam-me que é citada "a partir de Lemaistre de Sacy, Crampon ou Segond". Outros[as] autores[as] foram adicionados, ao longo da elaboração do dicionário, ao corpus inicial; a lista é dada no final do último volume. Nessa lista em que aparece, finalmente, o Plutarco de Amyot, assim como todo o conjunto de traduções de Perrot d'Ablancourt, após o nome do qual aparece, entre parênteses, uma breve lista de autores traduzidos por ele: "Cícero, Tácito, Arrian, Xenofonte, César, Lucien, Tucídides, etc.". E... a menos que eu esteja enganado, isso é tudo! Melhor do que nada, então - mas isso diz muito sobre as traduções consideradas aceitáveis pela lexicografia em meados do século XX. E essa situação pouco mudou desde então. E para medir o contraste, basta consultar o Dictionnaire allemand [Dicionário alemão] dos irmãos Grimm, descrição monumental da língua alemã, cujo primeiro volume apareceu em 1854 e que foi concluído apenas na segunda metade do século XX (em 1961, com um suplemento em 
1971); é possível constatar que, ao contrário, as traduções mais eminentes são frequentemente citadas ao longo dos artigos e não somente aquelas assinadas pelos maiores autores (como Schiller, Goethe, Wieland ou Schlegel), mas todas aquelas que tiveram um papel importante na construção do patrimônio intelectual da língua alemã, mesmo que seu[sua] "autor"[a] não tenha adquirido uma importância comparável pelas suas obras pessoais: Johann Heinrich Voss, tradutor de Virgílio e Homero, por exemplo, não pode ser excluído de nenhuma história literária e é considerado pelos lexicógrafos que o citam como um "autor". Muitas gerações, de fato, leram Homero na tradução de Voss, ou aprenderam a ler o latim de Virgílio com o auxílio da sua tradução: ou seja, leram o Homero de Voss, Homero como uma criação de Voss. Criação ou recriação, pouco importa! Segundo a tradução que é lida, não é o mesmo Homero, nem o mesmo Virgílio, com o qual estamos lidando. E não acontece diferentemente em nenhuma língua. E não acontece diferentemente para os[as] autores[as] modernos[as] nem para os[as] clássicos[as].

Sem dúvidas, é por isso que a literatura alemã oferece inúmeros exemplos de autores[as] dos quais é impossível separar "obra pessoal" e "obra de tradutor[a]": o caso mais eminente é, sem dúvida, o de Friedrich Rückert, um dos fundadores do orientalismo alemão, que estudou mais de 44 línguas, ensinou inúmeras na universidade, e de quem três quartos da obra poética são compostos por traduções de poemas que são verdadeiras recriações, abundantemente exploradas pelos compositores alemães e austríacos. A ideia de classificar Rückert entre os "simples" tradutores faria sorrir condescendentemente qualquer alemão culto; a ideia de negar que suas traduções, apesar de sua qualidade poética, sejam traduções e de "somente" as considerar como produções pessoais não viria a ninguém - não mais que a de publicar separadamente seus poemas "pessoais" (alguns dos quais, como as Canções para crianças mortas [Kindertotenlieder], musicados por Mahler, são muito célebres). Entretanto, na França, ainda em 1989, os editores (Claude Pichois e Jean Guillaume) do pri- 
meiro tomo das Euvres complètes [Obras completas] de Gérard de Nerval, para a Bibliothèque de la Pléiade [coleção Biblioteca da Pléiade], se recusaram a publicar as traduções de Nerval sob pretexto de que não se tratavam de textos "dele"; aumentando o paradoxo, frustrante para o leitor, ao reproduzir os artigos de Nerval sobre Heine e cortando as traduções dos poemas (e nem mencionemos as Poésies allemandes [Poesias alemãs] de 1829, das quais somente foi reproduzido o prefácio, excepcionalmente anotado por Lieven D'hulst, que deve ter sofrido por não poder editar também as próprias traduções). É verdade que essa edição (além de notável) tinha de fazer a difícil triagem entre os textos autênticos, oriundos verdadeiramente da pena de Nerval, e aqueles que lhe foram por muito tempo erroneamente atribuídos, devido aos múltiplos pseudônimos, aos quais ele recorreu para escrever em seu próprio tempo. Não obstante, traduções devidas a um grande autor jamais deveriam ser tratadas como apócrifos! Foi isso, entretanto, o que ocorreu com essa edição que, por um longo tempo e ainda hoje, é referência ${ }^{3}$.

\section{O[a] tradutor[a]: autor[a] segundo[a], mas primeiro[a] leitor[a]}

É, então, tempo (e eu sei que eu prego aos convertidos, mas nós não formamos ainda uma igreja muito grande) de reconhecer que a tradução é uma forma de criação; uma criação segunda, claro, mas uma forma de criação, um pouco diferente daquela de imitação e de múltiplas outras formas de reescrita que, entretanto, não se confundem com ela, sem dúvida. O estatuto criador das outras formas de reescrita é mais fácil de reconhecer, porque a tradução é uma reescrita sob constante restrição, uma re-criação sobre a qual se exerce, a todo momento, a presença restritiva de

\footnotetext{
${ }^{3}$ Eu desenvolvi a crítica que resumo aqui no prefácio de minha edição de traduções poéticas completas de Gérard de Nerval (1996).
}

Cad. Trad., Florianópolis, v. 39, no 3, p. 486-506, set-dez, 2019. 
um texto fonte que se deve, a princípio, seguir passo a passo. A princípio... pois está longe de ser sempre o mesmo caso - a adaptação (que implica uma tomada de liberdade) não perdeu seus direitos até hoje, não somente no teatro, mas em inúmeras outras áreas. Tudo acontece, então, como se assimilássemos criação e liberdade: donde, eu creio profundamente, a fascinação pela autotradução, à qual é consagrada uma quantidade considerável de estudos acadêmicos sem relação com sua importância real, ao menos do ponto de vista estatístico ${ }^{4}$. A autotradução permanece uma exceção e, se diz respeito a autores extremamente importantes como Beckett ou Nabokov, essa não é a única razão pela qual a tradutologia por ela se interessa tanto. O que fascina na autotradução, o que se encontra, precisamente, eliminado ou, melhor, em curto circuito, o que o regime "normal" (ordinário) da tradução tem de mais problemático e mais incômodo é a presença do[a] tradutor[a] como um[a] terceiro[a] que se interpõe entre o[a] autor[a] e o[a] leitor[a] - a fonte, então, dessa desconfiança consubstancial pela tradução, sobre a qual comentei anteriormente. Ora, o que falta na autotradução, nesse caso totalmente excepcional em que o[a] autor[a] se torna seu[sua] próprio[a] tradutor[a], é justamente essa restrição que sofre, por definição, o[a] tradutor[a] - o[a] autor[a] que se autotraduz não se traduz, ele[a] se reescreve inteiramente, livre para mudar tudo o que quiser, uma vez que não precisa prestar contas a si mesmo[a]. Aqui temos a certeza de lidar com o mesmo livro em duas línguas, com duas obras de criação "pura", que com certeza podemos comparar, mas sem poder desconfiar do pecado da infidelidade, ou seja, da liberdade.

$\mathrm{O}$ regime próprio à tradução é de ser uma reescrita sob restrição: e é, repitamos, o que faz com que se negue a sua natureza

\footnotetext{
${ }^{4}$ Ao estabelecer, em 2007, o Bilan des recherches sur la traduction en littérature comparée [Levantamento das pesquisas sobre a tradução na literatura comparada] (Masson 2007), fiquei impressionado com o número de teses e de ensaios sobre a autotradução: uma dezena entre 1995 e 2005 . A essas foram somadas, desde então, outras teses e inúmeros encontros e colóquios.
}

Cad. Trad., Florianópolis, v. 39, nº 3, p. 486-506, set-dez, 2019. 
criadora. Mas desde quando o fato de que uma escrita está sob restrição obriga a negar todo valor de criação? As restrições são desde sempre uma necessidade da criação literária, estejam elas fortemente codificadas - como aquelas às quais se submeteram os trovadores provençais ou, ainda, os Grandes Retóricos do século $\mathrm{XV}$ ou, dos nossos dias, os escritores da Oulipo - ou que sejam as mais sutis, ligadas, por exemplo, aos gêneros literários, às regras da prosódia etc., e, com certeza, às regras que o[a] escritor[a] impõe a si mesmo[a].

Existem, de fato, poucas formas de criação ex nihilo, esse é o sentido das célebres frases de Proust (1970) sobre a escrita como tradução em $O$ tempo redescoberto; o[a] próprio[a] escritor[a] não cria a partir do nada:

eu diria que, para exprimir tais sensações, para escrever esse livro essencial, o único verdadeiro, um grande escritor não precisa, no sentido corrente da palavra, inventá-lo, pois já existe em cada um de nós, e sim traduzi-lo. O dever e a tarefa do escritor são as do tradutor. (Proust 138)

Proust criou sua obra a partir de Mme de Sévigné, a partir de Saint-Simon, a partir de todas as leituras que fez, a partir de Ruskin de quem ele foi tradutor, a partir de Anatole France (figura tutelar de sua juventude) e de todos os outros escritores que ele pôde admirar, e com certeza a partir daquilo que ele próprio era, mas que pôde somente descobrir pela leitura, depois pelas diferentes formas de reescrita que são a tradução (mesmo que isso tenha acontecido com a ajuda de sua mãe) e o pastiche, sem esquecer da crítica literária.

O assunto sobre o qual tratamos aqui, o da tradução literária, em sua relação com a criação, revela, então, desafios que vão além das questões relacionadas à história das ideias, da lexicografia, da história da literatura ou da língua. São questões propriamente filo- 
sóficas, relativas a essa "tradutosofia"5 que Jean-René Ladmiral, criador desse belo neologismo, defende. Essas são todas questões relativas à tradição, e o parentesco com a tradução é evidente pela semelhança única entre as duas palavras. De fato, nós não criamos a nós mesmos. Nós somos criados[as] por toda a história que nos faz vir a ser, pelas pessoas que nos educaram, pelo país ao qual pertencemos, as viagens que fizemos, os quadros que vimos, os filmes que amamos... e todos os encontros que fizemos, o encontro com um[a] autor[a] há muito tempo desaparecido[a] podendo ser tão importante em uma vida como aquele com um[a] educador[a] ou um[a] amigo[a]. Nenhum[a] escritor[a] (e, mais geralmente, nenhum[a] artista) digno desse nome deveria poder alimentar a fantasia da criação ex nihilo, mesmo se isso existiu na história da literatura: a tábula rasa é sempre uma ilusão em matéria de criação artística. Ela pode existir apenas na filosofia, mas o gesto de Descartes visa somente a verdade, não a emoção, nada do que depende da sensibilidade, e da qual ele conhecia melhor que ninguém o preço. E para que Descartes rejeitasse todos os saberes adquiridos desde a infância, era necessário, ainda, que os tivesse recebido - a própria ideia da dúvida nunca teria vindo a um indivíduo inculto.

Simetricamente, ela também nunca virá a um pensador petrificado pelo respeito à tradição, à fé e a crenças herdadas de seus ancestrais. Isso, ainda, pode nos incitar a algumas reflexões sobre a tradução nas suas afinidades com a tradição. Se a primeira tradução de um texto é um ato corajoso e arriscado porque é inaugural, está bem claro que, a partir do momento em que esse texto é reconhecido como possuindo um valor primordial, essa única e primeira tradução não será suficiente; a retradução é um dos indícios mais fortes da canonização de um texto e a multiplicação das traduções contribui, em todas as culturas, para a constituição de um cânone literário. Pois esse cânone não saberia comportar unicamente as obras "nacionais", e não há exemplo de uma cultura digna desse nome que tenha sido fechada a todas as outras.

${ }^{5}$ [N.T.] Do francês, "traductosophie". 
A tradução é, então, em certa medida, "sacralizante". Pois uma de suas primeiras funções é precisamente criar um cânone: a tradução é criadora de valor, pois pode-se afirmar sem muitos riscos que o fato de traduzir um texto significa que atribui-se a ele, que reconhece-se nele, um certo valor (não necessariamente maior, mas um certo interesse, sem o qual não se o traduziria). E quando existe, de um texto, uma infinidade de traduções, quando um mesmo texto foi retraduzido cinco, dez, quinze, quarenta vezes, cem vezes ao longo dos séculos, ninguém pode negar que esse texto faça parte do cânone - a coletânea das cem traduções francesas do único poema completo de Sappho, reunidas por Philippe Brunet (1998), oferece um exemplo notável.

Mas a tradução é também, de uma outra maneira, dessacralizante: o[a] tradutor[a] que retraduz um texto define necessariamente seu trabalho contra aquele dos[as] tradutores[as] que o[a] precederam. Se o[a] primeiro[a] tradutor[a] ocupa um lugar único na história da recepção de um texto é porque, primeiro, não há alguém contra quem tomar posição, então todos os[as] seus[suas] sucessores[as] se definirão contra ele[a]. Não seria seu desejo recomeçar tudo do zero, de então "fazer tábula rasa" das traduções precedentes (o que nunca é completamente possível, mas o provar nos levaria muito longe); com a insatisfação que ele[a] experimenta em relação às versões anteriores, o[a] "retradutor" [a] opera necessariamente um rejuvenescimento do texto. Tenha três ou dez ou trinta séculos, o texto que foi recém traduzido é muito novo: ele acabou de (re)nascer.

É assim que a vida de um texto prossegue em diferentes línguas, à maneira de uma "criação contínua" - prosseguindo notadamente de tradução em tradução, à medida em que as línguas alvo mudam, evoluem, e com elas a sensibilidade dos[as] leitores[as] (o[a] tradutor[a] é um deles[as]) que, de século em século, encontram em uma mesma obra outras significações. Se a leitura é criadora de sentido, como se reconhece há muito tempo, antes de tudo graças à Proust, a tradução está no degrau supremo, na medida em que ela pode se definir como uma "escrita-leitura" e em que toda tradução é o traço de uma leitura. Roland Barthes apresentou esse fenômeno crucial 
para a literatura em um parágrafo de Crítica e verdade que passa, infelizmente, ao largo do problema da tradução:

uma obra é "eterna" não porque ela impõe um sentido único a homens diferentes, mas porque ela sugere sentidos diferentes a um homem único, que fala sempre a mesma língua simbólica através dos tempos múltiplos: a obra propõe, o homem dispõe. (212)

Esse "homem único" do qual fala Barthes, cuja teoria da leitura naquela época $(1966 ; 2007)$ se esforçava ainda em reduzir o[a] leitor[a] a uma função sem subjetividade, existe, certamente, apenas como outra figura de pensamento; a superioridade de Proust é de colocar a subjetividade no coração de seu pensamento. É por isso que Proust se preocupa com a tradução, contrariamente a Barthes, que nem mesmo sonha aqui que, para falar a "mesma língua simbólica" de geração em geração, o indivíduo fala antes de tudo, e sempre, uma língua particular que nunca é "a" língua nem a linguagem. Não somente o sentido de que um texto não cessa de advir e de se criar de leitor[a] em leitor[a], ao longo do tempo, no interior de uma mesma língua, mas em cada uma das línguas nas quais o texto foi, é e será traduzido, e esse sentido se enriquece, se desenvolve, através da dupla subjetividade do[a] tradutor[a] e de seus leitores. O[a] tradutor[a] é certamente um[a] "autor[a] segundo[a]", mas é também, por outro lado, um[a] "primeiro[a] leitor[a]" de quem dependerão todos[as] os[as] outros[as] leitores[as] de sua tradução, a qual entra em concorrência com todas aquelas que a precederam ou que a sucederão. A sugestão de "sentidos múltiplos" que opera todo texto ao longo da história é obra dos[as] leitores[as], pois a leitura também se configura como obra: a leitura é criadora de sentido. Mas nos é permitido dizer que a tradução, enquanto leitura, o é no grau supremo. O[a] tradutor[a] como "primeiro[a] leitor[a]", de acordo com a ordem cronológica, é também "leitor[a] primeiro[a]" no sentido qualitativo do termo: ele[a] é 
provavelmente, junto ao copista (essa figura desaparecida do campo literário, mas que ocupa há muito tempo o primeiro lugar), o[a] único[a] leitor[a] que prestou plena e igual atenção à cada palavra do texto e seguiu o[a] autor[a] passo a passo como sua sombra, ou seu duplo. Aquele[a] a quem, idealmente, a distração não é permitida (mesmo que, como o copista, chegue a ficar sonolento[a]...), aquele[a] que não tem o direito de saltar uma linha.

Afirmar que a tradução não é criadora é, então, uma opinião de visão estreita, uma evidência de que a reflexão convida a ultrapassar, como o fazem os[as] contribuidores[as] dessas jornadas que nos reuniram em Avignon. Se nós chegamos, pelos nossos trabalhos, a provocar uma tomada de consciência da necessidade de levar em consideração o aporte criador das traduções, as consequências serão imensas e enormes campos irão se abrir. Nós vimos que era necessário que quase todos os dicionários da língua francesa fossem refeitos, se quiséssemos levar em conta o que se deve aos[às] tradutores[as] no movimento histórico da língua. Uma outra consequência seria, provavelmente, estudar a parte das traduções na constituição do patrimônio intelectual das diferentes línguas. É a esse projeto que respondem, para a língua francesa (muito além dos limites territoriais da França, portanto), o projeto da Histoire des traductions en langue française [História das traduções em língua francesa], que eu tive a honra de co-organizar com Yves Chevrel, assim como, para a língua inglesa, The Oxford History of Literary Translation in English [O Oxford da História da Tradução Literária em Inglês], organizado por Peter France e Stuart Gillespie, que obedece a modalidades ligeiramente diferentes (nossa História não se limita somente às traduções "literárias", mesmo que literary translation [tradução literária] inclua, para os autores de tal trabalho monumental, mais do que a simples "literatura", notadamente a história e a filosofia). A noção de "patrimônio intelectual” é aquela que nos pareceu mais apropriada para designar o conjunto de traduções que, em todas as áreas do saber, dos conhecimentos técnicos e também do entretenimento, enriqueceram a língua ao importarem obras de todos os tipos, vindas do estrangeiro. Fazendo isso, nós 
recusamos a distinção operada por Antoine Berman entre a "tradução de obras" (ou seja, de textos literários nos quais se opera um verdadeiro trabalho de estilo) e aquela que ele tinha o costume de chamar "palavra oca" - à sua maneira, livros de fé ou manuais técnicos fazem parte, também, do patrimônio de uma língua e foram muito traduzidos ao longo do tempo!

Sim, é importante revisitar a história da literatura de diferentes países do mundo. E se lembrar que a atualidade literária de uma determinada época sempre foi composta por traduções que também foram capazes de "causar impacto". Que os[as] leitores[as] sempre leram livros "originais" e traduções. Que os[as] escritores[as] são, também (talvez mesmo a princípio), leitores[as] e que, graças às traduções, eles[as] tomaram conhecimento das literaturas estrangeiras. Evidências? Sem dúvida, mas nós vimos quantas delas foram refutadas. Uma vez esclarecidas as razões dessa refutação, como tentamos aqui iniciar, torna-se urgente ultrapassá-la.

\section{Agradecimentos}

Agradeço a Marine Charmasson e Louisa Derdar por transcreverem a conferência a partir da qual o presente artigo é a emenda completa e, eu espero, melhorada.

\section{Referências}

Barthes, Roland. Critique et vérité. Tel quel. Paris: Seuil, 1966.

Barthes, Roland. Crítica e verdade. Tradução de Leyla Perrone-Moisés. São Paulo: Perspectiva, 2007.

Berman, Antoine. La traduction et la lettre ou l'auberge du lointain. Paris: Seuil, 1991. 
Berman, Antoine, Granel, Gérard, Jaulin, Annick et al. Les Tours de Babel: essais sur la traduction. Mauzevin: Trans Europ Repress, 1985.

Masson, Jean-Yves. "Bilan des recherches sur la traduction en littérature comparée". La Recherche en littérature générale et comparée en France en 2007. Dir. Anne Tomiche e Karl Zieger. Valenciennes: Presses universitaires de Valenciennes, 2007. p. 67-79.

Meschonnic, Henri. Au commencement. Traduction de la Genèse. Paris: Desclée de Brouwer, 2002.

Montesquieu, Charles de Secondat, barão de. Cartas persas. Tradução de Rosemary Costhek Abílio. São Paulo: WMF Martins Fontes, 2009.

Nerval, Gérard de. Poèmes d'Outre-Rhin. Dirigé par Jean-Yves Masson. Paris: Grasset, 1996.

Proust, Marcel. O tempo redescoberto. Tradução de Lúcia Miguel Pereira. Vol. 7. Porto Alegre: Globo, 1970.

Sappho. "L'égal des dieux". Cent versions d'un poème. Dir. Philippe Brunet. Paris: Allia, 1998.

Recebido em: 10/04/2019

Aceito em: 04/06/2019

Publicado em: Setembro de 2019

Jaqueline Sinderski Bigaton. E-mail: jaquelinesinderski@gmail.com ORCID: http://orcid.org/0000-0003-2168-4846

Francisca Y. M. Reyes Silveira. E-mail: fran.ysabella@gmail.com ORCID: https://orcid.org/0000-0002-1125-2380 